\title{
Influence of Arbuscular Mycorrhizal Fungi (AMF) Inoculation on Growth and Mycorrhizal Dependency of (Lens culinaris L.) Varieties
}

\author{
Shah Wali Khan ${ }^{1, ~}$, Tabassum Yaseen ${ }^{2}$, Falak Naz ${ }^{1}$, Syed Abidullah ${ }^{1}$, Mohammad Kamil ${ }^{1}$ \\ ${ }^{1}$ Department of Botany, Abdul Wali Khan University, Mardan, Pakistan \\ ${ }^{2}$ Department of Botany, Bacha Khan University, Charsadda, Pakistan
}

Email address:

shahawkum44@yahoo.com (S. W. Khan)

${ }^{*}$ Corresponding author

\section{To cite this article:}

Shah Wali Khan, Tabassum Yaseen, Falak Naz, Syed Abidullah, Mohammad Kamil. Influence of Arbuscular Mycorrhizal Fungi (AMF) Inoculation on Growth and Mycorrhizal Dependency of (Lens culinaris L.) Varieties. International Journal of Bioorganic Chemistry. Vol. 4, No. 1, 2019, pp. 47-52. doi: 10.11648/j.ijbc.20190401.17

Received: February 9, 2019; Accepted: March 25, 2019; Published: April 22, 2019

\begin{abstract}
Arbuscular mycorrhizal fungi (AMF) are soil fungi, obligate biotrophic fungi and form the most common mutualistic symbiosis in nature: the arbuscular mycorrhiza (AM). This association occurs on the roots of most plants, promoting improvements in plant growth and development. The present study was aimed to investigate the effect of arbuscular mycorrhizal fungi (Glomus aggergatums, Glomus fasciculatum, Glomus mosseae and Sclerocystis niger) inoculation on growth and mycorrhizal dependency of Lens culinaris L. varieties. The experiment was carried out under natural condition with two treatments (inoculated and control) in triplicates. Inoculation of lentil plants with arbuscular mycorrhizal fungi resulted a significant increase in various plant growth parameters compared to plants without inoculation. In addition, fungal inoculation significantly increased mycorrhizal dependency as compared to un-inoculated plants. It is concluded that fungal inoculation improve plant growth parameters under phosphorous deficient soil.
\end{abstract}

Keywords: AM Fungi, Growth, Mycorrhizal Dependency, Lens culinaris, Inoculation

\section{Introduction}

The word mycorrhiza is originated from two Greek words myco meaning fungi and Rrhiza meaning root and its' meaning in reality means symbiosis between a fungus and root of the other plants. Mycorrhiza is described as a mutual sharing of life; whereby the fungal is the major partner of the plant has the duty to supply food, growth hormones and protection of plants' root from pathogens and a fine plant will offer high energetic material to the fungus [1]. Mycorrhizal fungi are one of the soil organisms that form a direct link between the soil and plant root systems [2].

It is well known that AM symbiosis can increase plant growth and nutrient uptake, improve fruit quality and enhance several abiotic stresses such as low temperature stress, drought, salt stress, etc. [3]. Arbuscular mycorrhizal fungi (AMF) colonization increased growth of chickpea up to $+43 \%$ of total dry matter [4]. Colonization of roots by AM fungi has been shown to improve growth and productivity of several field crops [5-7] by increasing nutrient element uptake [8]. Mycorrhizal fungi are beneficial association of microorganisms with their extra metrical hyphae, which increase plant growth and yield through increase absorption of relatively immobile elements in soil such as $\mathrm{P}, \mathrm{Cu}$ and $\mathrm{Zn}$ by substantially extending the area of absorption beyond that of root hairs [3]. Many workers studied that arbuscular mycorrhizal (AM) fungi inoculation had a significant effect on the growth and productivity of legumes when compared with non-mycorrhizal plants [9-13].

\section{Materials and Methods}

This experiment was carried out at the Department of Botany, Bacha Khan University Charsadda Khyber Pakhtunkhwa-Pakistan during winter season 2014-2015. The site lies between $34^{\circ} \mathrm{N}$ to $38^{\circ} \mathrm{N}$ latitude and between $71^{\circ} \mathrm{E}$ to 
$53^{\circ} \mathrm{E}$ longitude. In the experimental work, rhizospheric soil of maize field having 123/100 gm spores number of different AMF species Glomus fasciculatum, Glomus mosseae and Glomus aggregatum and roots of infected with AMF were used as inoculum. These roots along with soil used as an AMF inoculum and spread uniformly in layer at a depth of 3$6 \mathrm{~cm}$ before sowing. Each pot was filled with $4 \mathrm{~kg}$ of soil.

Physio-chemical properties of soil was done by the methods of [14]. Soil had $(70 \%$ sand, $25 \%$ silt, $10 \%$ clay, texture sandy loamy soil, $24.4 \% \mathrm{CaCO}_{3}, \mathrm{pH} 7.41$, E.C. 1.2 $\mathrm{dS} \mathrm{m}{ }^{-1}$ and ionic concentrations were, $\mathrm{Ca}^{++} 11.9 ; \mathrm{Mg}^{++} 8.1$; $\mathrm{Na}^{+}$2.35; $\mathrm{K}^{+} 1.28 ; \mathrm{CO}_{3}{ }^{--}$traces; $\mathrm{HCO}_{3}{ }^{-}$8.52; $\mathrm{Cl}^{-} 1.6 ; \mathrm{NO}_{3}$ traces and $\mathrm{SO}_{4}^{--} 6.1 \mathrm{mg} \mathrm{Kg}{ }^{-1}$ soil . Total nitrogen and phosphorus were 2.21 and $1.43 \mathrm{mg} \mathrm{Kg}^{-1}$ soil, respectively.

The experiment was laid out in a randomized block design (RCBD) following two treatments (control and inoculated), each treatment was replicated three times (Two treatments $\times 3$ varieties of lentils $\times 3$ replicates). The following parameters were recorded: Agronomic parameters including plant height, fresh and dry weight and number of branches/plant was known at two different stages (vegetative and harvesting). Mycorrhizal dependency (MD) value of selected legumes was calculated by the formula given by Plechentte \& Furlan [14].

\section{Results and Discussion}

In this research work Lens culinaris varieties mycorrhizal inoculated and control plants were grown in P-deficient soil. The objectives of the present study was to investigate the responsiveness of lentil, a legume to arbuscular mycorrhizal fungi inoculation on the growth and mycorrhizal dependency. The result showed that mycorrhizal inoculated plants increased plant growth parameters of inoculated plants as compared with control. Inoculated plants significantly $(\mathrm{P}<0.05)$ enhanced the growth parameters including plant height, fresh and dry weight, number of branches/plant of lentils. Our results agree with Yaseen et al., [15] studied the effects of mycorrhizal fungal inoculation on seed germination and plant growth of Bambara groundnut (Vigna subterranea). The fungal strains significantly increased plant growth parameters e.g. number of leaves, leaf length, leaf surface area, stem girth and number of shoots respectively. The present study also confirm the findings that the inoculation of Rhizobium, rock phosphate and Vesicular Arbuscular Mycorrhizae (VAM) significantly increased the growth parameters and growth yield of Burgundy (Macroptilum bracteatum) under "P" deficient soil [17]. The endophytic fungi significantly increased shoot growth, chlorophyll contents, and plant biomass and leaf area of pepper plant as compared to fungal-free plants [16]. AM fungi inoculation had a significant effect productivity of Chickpea attributed to growth, viz., and plant height, no. of nodules, mycorrhizal dependency and flowers per plant [32]. In the present study the following growth parameters mycorrhizal and non-mycorrhizal plants of lentil varieties were recorded and compared.

\subsection{Plant Height}

Results of AM fungi inoculation on plant height of three different varieties of lentil (NARC 11-4, Masoor Markaz 09 and Masoor 2002) following two treatments inoculated and control are given in LSD Table 1 and Figures 1-2. The maximum plant height at vegetative stage was $(9.3167 \mathrm{~cm})$ recorded in variety Masoor 2002 followed by NARC 11-4 $(8.5250 \mathrm{~cm})$ and Masoor Markaz 09 with $(7.8750 \mathrm{~cm})$. At harvesting maximum $(16.667 \mathrm{~cm})$ plant height was recorded for NARC 11-4 followed by Masoor 2002 with $(15.583 \mathrm{~cm})$. The results revealed that mycorrhizal application in nutrient deficient soil increased plant height as compared with control.

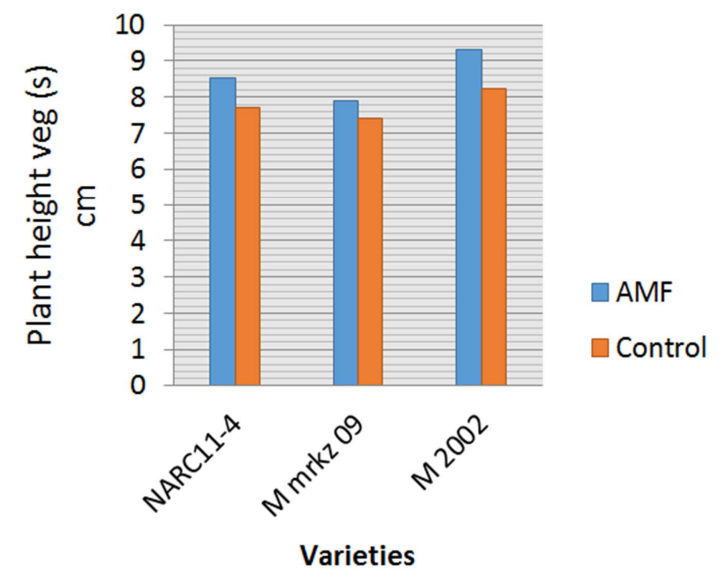

Figure 1. Influence of AMF on plant height at vegetative stage.

The interaction between varieties and the effect of treatments were significantly different regarding plant height. The results showed that mycorrhizal plants were taller as compared with non-inoculated plants. Our results correlate with the findings of Smith SE et al. [18] who compared uninoculated mycorrhizal plants with AM fungal inoculated plants, plant height was significantly increased by $30.3 \%$ in red tangerine (Citrus tangerine). Our results also correlate with the findings of Oluwatomiwa, [19] observed that inoculation of plant with (AM) fungi improved plant growth due to increase $\mathrm{N}_{2}$ fixation and similarly by Thakur et al. [20] resulted that the symbiosis between plants and arbuscular mycorrhizal fungi efficiently promote plant growth especially in growth limiting environment.

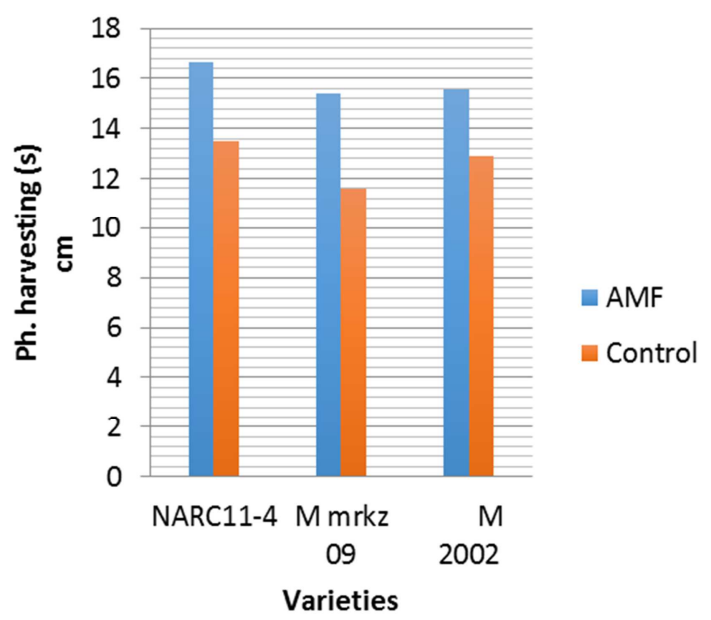

Figure 2. Influence of AMF on plant height at harvesting stage. 


\subsection{Fresh and Dry Weight}

Results of AM fungi inoculation on plant fresh and dry weight of three different varieties of lentil (NARC 11-4, Masoor Markaz 09 and Masoor 2002) following two treatments inoculated and control are given in LSD Table 1 and Figures 3-6. Analysis of the data showed that mycorrhizal inoculation increased fresh and dry weight of plants at both stages and had a significant effect compared to control plants. The interaction between varieties and the effect of treatments were significantly different regarding plant dry weight and the effect of treatments were significantly different in terms of plant fresh weight. The results were consistent to Udaiyan [21] that the inoculation of onion plants with AM fungi can significantly increase bulb diameter, bulb yield, shoot dry and fresh weights and shoot phosphorus content. The present results are also agree with the findings of Mudalagiriyappan et al. [22] reported that the AMF inoculation increased the root, shoot and total dry matter production in Mungbean. Inoculation of Glomus fasciculatum with plants of Casuarina equisetifolia, results in the higher growth and biomass [23]. AMF inoculation significantly increased in dry matter production, improved growth rate and net assimilation rate [24].

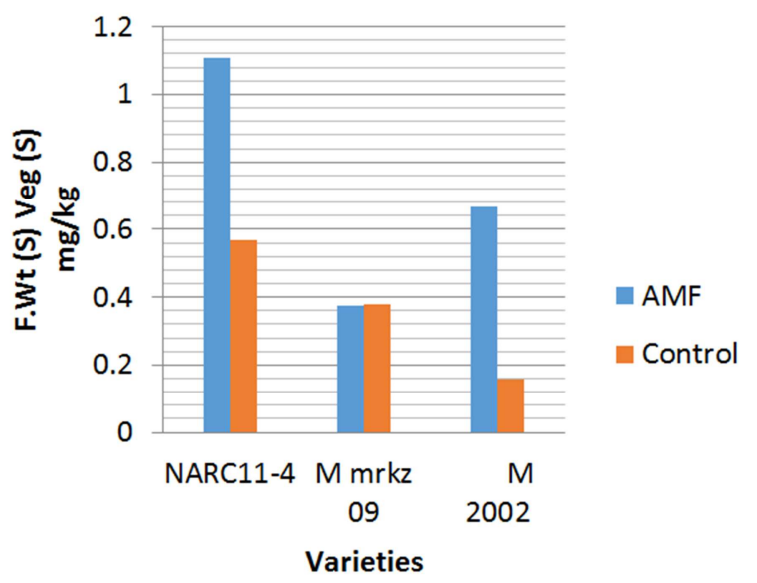

Figure 3. Influence of AMF on fresh shoot weight at vegetative stage.

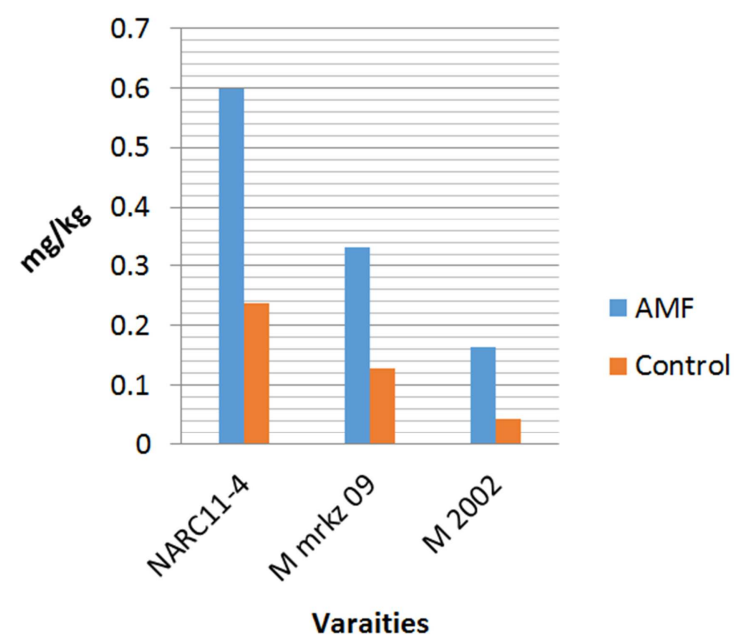

Figure 4. Influence of AMF on fresh shoot weight at harvesting stage.

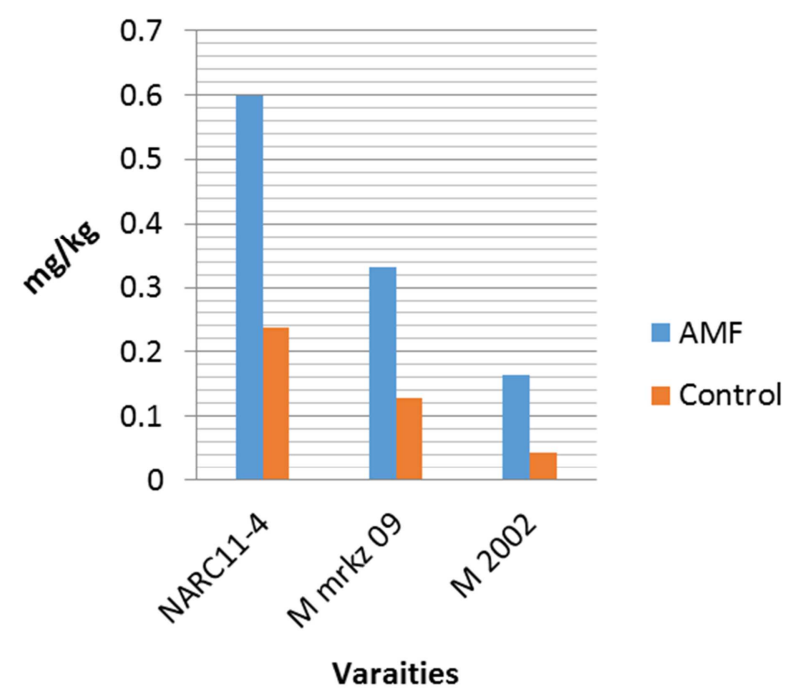

Figure 5. Influence of AMF on dry shoot weight at vegetative stage.

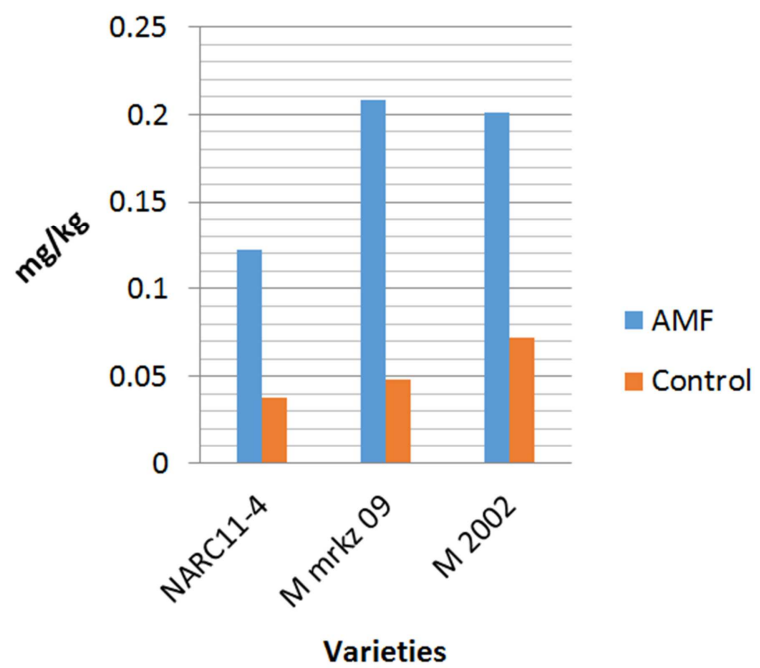

Figure 6. Influence of AMF on dry shoot weight at harvesting stage.

\subsection{Number of Branches/Plant}

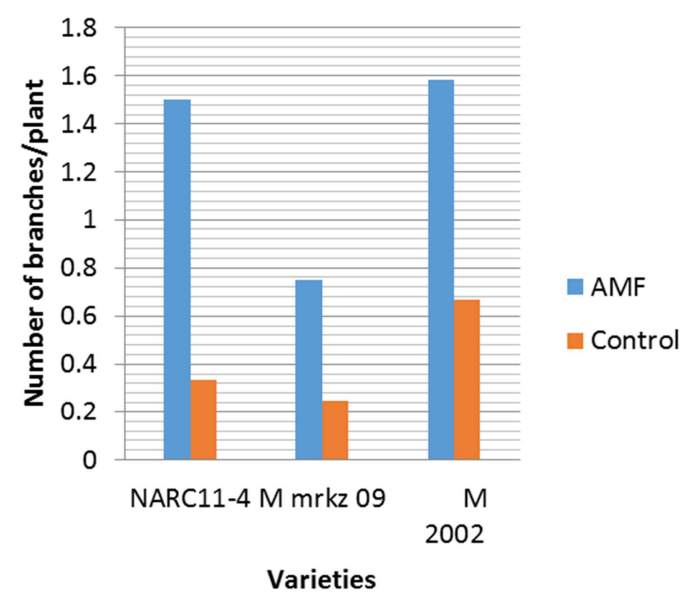

Figure 7. Influence of AMF on number of branches/plant.

Results of AM fungi inoculation on number of branches/plant of three different varieties of lentil (NARC 
11-4, Masoor Markaz 09 and Masoor 2002) following two treatments inoculated and control are given in LSD Table 1 and Figure 7. It is observed that maximum number of branches (1.5833) was found in Masoor 2002 followed NARC 11-4 with (1.5000) as compared with control plants. The present study evaluate the significant effect of AMF on number of branches/plant. Our results is a good conformity that the AM fungi (Glomus intraradices) and (Glomus mosseae) have been studied for various plant growth promoting activities and reported to positively influence the growth of various plant species [3, 25-26]. AM fungal inoculation had greater shoot number and diameter than nonAM seedlings, because mycorrhizal fungi are known to improve growth and nutrients particularly $P$ [8-27]. Arbuscular mycorrhizal fungi inoculation increased plant growth in inoculated plants as compared with non-inoculated plants [28].

Table 1. Effect of arbuscular mycorrhizal fungi (AMF) inoculation on growth parameters of Lens culinaris $M$.

\begin{tabular}{|c|c|c|c|c|c|c|c|}
\hline \multirow{2}{*}{ Varieties } & \multirow{2}{*}{ Treatments } & \multirow{2}{*}{ Stages } & \multirow{2}{*}{ Height (cm) } & \multirow{2}{*}{$\begin{array}{l}\text { Fresh } \\
\text { Weight of shoot } \mathrm{mg} / \mathrm{kg}\end{array}$} & \multirow{2}{*}{$\begin{array}{l}\text { Dry } \\
\text { Weight of shoot } \mathrm{mg} / \mathrm{kg}\end{array}$} & \multirow{2}{*}{$\begin{array}{l}\text { Fresh } \\
\text { Root weight } \mathrm{mg} / \mathrm{kg} \\
\end{array}$} & \multirow{2}{*}{$\begin{array}{l}\text { No. of } \\
\text { branches }\end{array}$} \\
\hline & & & & & & & \\
\hline \multirow{4}{*}{ NARC 11-4 } & \multirow{2}{*}{ AMF } & Vegetative & 8.5250 & 1.1093 & 0.5984 & 0.0854 & \multirow{2}{*}{1.5000} \\
\hline & & Harvesting & 16.667 & 0.5434 & 0.1220 & 0.2403 & \\
\hline & \multirow{2}{*}{ Control } & Vegetative & 7.7250 & 0.5690 & 0.2382 & 0.0315 & \multirow{2}{*}{0.3333} \\
\hline & & Harvesting & 13.510 & 0.0908 & 0.0376 & 0.1550 & \\
\hline \multirow{3}{*}{ Masoor markz 09} & AMF & Vegetative & 7.8750 & 0.3740 & 0.3311 & 0.1412 & 0.7500 \\
\hline & \multirow{2}{*}{ Control } & Vegetative & 7.4000 & 0.3785 & 0.1284 & 0.0411 & \multirow{2}{*}{0.2500} \\
\hline & & Harvesting & 11.583 & 0.0835 & 0.0483 & 0.1547 & \\
\hline \multirow{4}{*}{ Masoor 2002} & \multirow{2}{*}{ AMF } & Vegetative & 9.3167 & 0.6665 & 0.1645 & 0.2948 & \multirow{2}{*}{1.5833} \\
\hline & & Harvesting & 15.583 & 0.1095 & 0.2011 & 0.2667 & \\
\hline & \multirow{2}{*}{ Control } & Vegetative & 8.2417 & 0.1591 & 0.0433 & 0.0328 & \multirow{2}{*}{0.6667} \\
\hline & & Harvesting & 12.917 & 0.0923 & 0.0717 & 0.1733 & \\
\hline
\end{tabular}

All values mean \pm SEM of 3 determinations (replicates)

\subsection{Mycorrhizal Dependency (M.D)}

Mycorrhizal dependency is a value of measurement that, how much plant depends on Arbuscular mycorrhizal (AM) fungi for its growth and development [29]. Results of arbuscular mycorrhiza (AM) fungi inoculation on mycorrhizal dependency of lentil varieties following two treatments inoculated and control are given in Table 2 and Figure 8 . Results revealed that the maximum dry weight was $(0.2084 \mathrm{gm} / \mathrm{kg})$ recorded for variety Masoor markaz 09 as compared to control plants having less weighed at harvesting stage than the inoculated plants. Maximum mycorrhizal dependency value was recorded $(76.82 \%)$ for variety Masoor markaz 09 followed by NARC 11-4 with (69.18\%) and Masoor 2002 with (64.34\%) respectively in mycorrhizal inoculated plants. Masoor markaz 09 and NARC 11-4 varieties are more dependent on mycorrhiza and variety Masoor 2002 are less dependent on mycorrhiza. Our result agree with Nazir et al., [30] reported that, high mycorrhizal dependency value increased plant growth by arbuscular mycorrhiza activity in M. lacerata, M. luisana, $M$. polyantha and M. texana species. From the present study we found that legumes were more dependent on mycorrhizal association for better survival, in nutrient deficient soil. Our results also correlate with $\mathrm{Wu}$ et al., [31] observed, that plant species and even cultivars of same species having different mycorrhizal dependency value due to soil type, root geometry, plant growth rates, mycorrhizal species and soil phosphorus.
Table 2. Means of dry weight of four replicates of mycorrhizal dependency.

\begin{tabular}{llll}
\hline Varieties & Treatments & $\begin{array}{l}\text { Means of dry wt. } \\
\text { of four replicates }\end{array}$ & M.D\% \\
\hline \multirow{2}{*}{ NARC 11-4 } & AMF & 0.1220 & $69.18 \%$ \\
Masoor markaz & Control & 0.0376 & \\
09 & AMF & 0.2084 & $76.82 \%$ \\
Masoor 2002 & Control & 0.0483 & \multirow{2}{*}{$64.34 \%$} \\
\hline
\end{tabular}

Mean dry weight of four replicates

Mycorrhizal dependency (M.D)

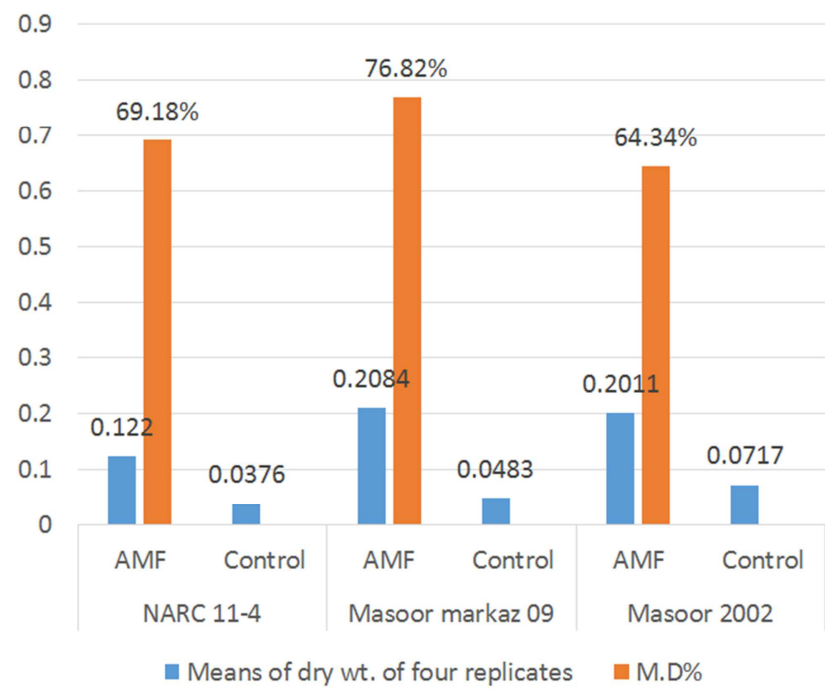

Figure 8. Mycorrhizal dependency index (M.D). 


\section{Conclusion}

In conclusion, our results have confirmed the important effects of AM fungal inoculation on lentil growth parameters and mycorrhizal dependency. These results show a significant application of AM fungal inoculation for agricultural development in areas having P-deficient soil. The symbiosis with mycorrhiza is a biological technology that may improve growth parameters and mycorrhizal dependency in leguminous plants for an agricultural development and to maintain friendly ecosystem.

\section{Acknowledgements}

The authors thank to all staff of Agriculture Chemistry Department, University of Agriculture, Peshawar, Pakistan.

\section{References}

[1] Alizadeh, O. Nadian, H. A. (2010). Evaluation effect of water stress and nitrogen rates on amount of absorption some macro and micro elements in corn plant mycorrhizae and nonmycorrhizae. Research Journal of Biological Sciences 5, 350355.

[2] Alizadeh, O. Namazi L. (2011). Effect of Different Irrigation Levels on Nutrient Uptake by Mycorrhizal and NonMycorrhizal Corn Plants as Affected by Different Soil Phosphorus Content. Advances in Environmental Biology 5(8), 2317-2321.

[3] Miransari M, Bahrami HA, Rejali F, Malakouti MJ, Torabi H. (2007). Using arbuscular mycorrhiza to reduce the stressful effects of soil compaction on corn (Zea mays L.) growth. Soil Biology and Biochemistry 39(8), 2014-26.

[4] Farzaneh M, Vierheilig H, Loss A, Kaul HP. (2011). Arbuscular mycorrhiza enhances nutrient uptake in chickpea. Plant Soil and Environment 57(10), 465-470.

[5] Cavagnaro TR, Jackson LE, Six J, Ferris H, Goyal S, Asami D, Scow KM. (2006). Arbuscular mycorrhizas, microbial communities, nutrient availability, and soil aggregates in organic tomato production. Plant and Soil 282, 209-225.

[6] Pasqualini D, Uhlmann A, Stumer SL. (2007). Arbuscular mycorrhizal fungal communities influence growth and phosphorus concentration of woody plants species from the Atlantic rain forest in South Brazil. Forest Ecology and Management 245(13), 148-55.

[7] Thenua OV, Singh SP, Shivakumar BG. (2010). Productivity and economics of chickpea (Cicer arietinum)-fodder sorghum (Sorghum bicolor) cropping system as influenced by $\mathrm{P}$ sources, bio-fertilizers and irrigation to chickpea. Indian Journal of Agronomy 55(1), 22-7.

[8] Al-Karaki, G. N. (2006). Nursery inoculation of tomato with arbuscular mycorrhizal fungi and subsequent performance under irrigation with saline water. Scientia Horticulturae 109, $1-7$.

[9] Rohyadi A, Smith FA, Murray RS, Smith SE. (2004). Effects of $\mathrm{pH}$ on mycorrhizal colonisation and nutrient uptake in cowpea under conditions that minimise confounding effects of elevated available aluminium. Plant and soil 260(1-2): 283-
90.

[10] Singh AP, Chaturvedi S, Tripathi MK, Singh S. (2004). Growth and yield of green gram (Vigna radiata (L.) Wilczek) as influenced by biofertilizer and phosphorus application. Annals of Biology (India) 20(2), 227-232.

[11] Jalaluddin M. (2005). Effect of inoculation with VAM fungi and Bradyrhizobium on growth and yield of soybean in Sindh. 37(1), 169-173.

[12] Avis, TJ, Gravel V, Antoun H, Tweddell RJ. (2008). Multifaceted beneficial effects of rhizosphere microorganisms on plant health and productivity. Soil Biology and Biochemistry 40(7), 1733-1740.

[13] Nelson DW, Sommers L. (1982). Total carbon, organic carbon, and organic matter 1. Methods of soil analysis. Part 2. Chemical and microbiological properties (methodsofsoilan2): 539-79.

[14] Plenchette C, Fortin JA, Furlan V. (1983). Growth responses of several plant species to mycorrhizae in a soil of moderate P-fertility. Plant and soil 70(2), 199-209.

[15] Yaseen T, Hussain F, Rahman HU, Noor M. (2013). Change in growth and productivity of burgundy due to rock phosphate, VAM and Rhizobium inoculation. Sarhad Journal Agriculture 29(4), 537-42.

[16] Khan AL, Shinwari ZK, Kim YH, Waqas M, Hamayun M, Kamran M, Lee IJ. (2012). Pakistan Journal of Botany 44(5), 1601-1607.

[17] Tabassum Y, Tanvir B, Farrukh H. (2012). Effect of arbuscular mycorrhizal inoculation on nutrient uptake, growth and productivity of chickpea (Cicer arietinum) varieties. International journal of agronomy and plant production 3(9), 334-45.

[18] Smith SE, Read DJ. (2008). Mycorrhizal Symbiosis 3rd edn Academic Press: San Diego. CA, USA 787.

[19] Oluwatomiwa OS, Awodun MA. (2014). Influence of Mycorrhizae and Rhizobium Inoculation on Growth, Nutrient Uptake and Proximate Composition of Upland Rice Cultivars. J. Natural Sci. Res., 4(24). ISSN (Paper) 2224-3186 ISSN (Online), 2225-0921.

[20] Thakur AK, Pamwar JDS. (1995). Effect of Rhizobiumarbuscular mycorrhiza interaction of growth and yield in mungbean (Vigna radiata (L.) Wilczek) under field conditions. Indian Journal of Plant Physiology 37(1), 62-65.

[21] Udaiyan K, Sugavanam V. (1996). Interaction of arbuscular mycorrhizal fungi and Frankia spp. On Growth and nutrient uptake in Casuarina equisetifolia Forst. Mycorrhizal: Biofertilizers for the future 230-237.

[22] Mudalagiriyappan CA, Agasimani KK, Veeranna S, Najappa HV. (1997). Nutrient recovery and balance sheet of nitrogen and phosphorus as influenced by sources of phosphate solubilizers and phosphate on groundnut. Mysore Journal of Botany 32:143-8.

[23] Xu P, Christie P, Liu Y, Zhang J, Li X. (2008). The arbuscular mycorrhizal fungus Glomus mosseae can enhance arsenic tolerance in Medicago truncatula by increasing plant phosphorus status and restricting arsenate uptake. Environmental Pollution 156(1), 215-20. 
[24] Bedini S, Pellegrino E, Avio L, Pellegrini S, Bazzoffi P, Argese E, Giovannetti M. (2009). Changes in soil aggregation and glomalin-related soil protein content as affected by the arbuscular mycorrhizal fungal species Glomus mosseae and Glomus intraradices. Soil Biology and Biochemistry 41, 14911496.

[25] Carretero CL, Cantos M, Garcia JL, Azcon R, Troncoso A. (2009). Growth responses of micropropagated cassava clones as affected by Glomus intraradices colonization. Journal of Plant Nutrition 32, 261-273.

[26] Tang M, Chen H, Huang JC, Tian ZQ. (2009). AM fungi effects on the growth and physiology of Zea mays seedlings under diesel stress. Soil Biology and Biochemistry 41(5), 93640 .

[27] Manoharan PT, Shanmugaiah V, Balasubramanian N, Gomathinayagam S, Sharma MP, Muthuchelian K. (2010). Influence of AM fungi on the growth and physiological status of Erythrina variegata Linn. Grown under different water stress conditions. European Journal of Soil Biology 46(2), 151-6.

[28] Antunes P. M, Deaville D, Goss M. J. (2006). Effect of two AMF life strategies on the tripartite symbiosis with Bradyrhizobium japonicum and soybean. Mycorrhiza. 16, 167-173.

[29] Bhat SA, Thenua OVS, Shivakumar BG, Malik JK. (2005). Performance of summer green gram [Vigna radiata (L.) Wilczek] as influenced by biofertilizers and phosphorus nutrition. Haryana Journal of Agronomy 21(2), 203-205.

[30] Nazir H, Hassan B, Habib R, Chand L, Ali A, Hussain A. (2011). Response of bio- fertilizers on growth and yield attributes of blackgram. International Journal of Current Research 2(1), 148-50.

[31] Wu QS, Zou YN, Xia RX, Wang MY. (2007). Five Glomus species affect water relations of Citrus tangerine during drought stress. Botanical Studies 48(2), 147-54. 